\title{
Non-Alcoholic and Craft Beer Production and Challenges
}

\author{
Liana Claudia Salanță ${ }^{1}\left(\mathbb{D}\right.$, Teodora Emilia Coldea ${ }^{2, *}$, Maria Valentina Ignat ${ }^{2}$, \\ Carmen Rodica Pop ${ }^{1} \mathbb{D}$, Maria Tofană ${ }^{1}$, Elena Mudura ${ }^{2} \mathbb{D}$, Andrei Borșa ${ }^{2} \mathbb{D}$, \\ Antonella Pasqualone ${ }^{3}$ (D) and Haifeng Zhao 4 (D) \\ 1 Department of Food Science, Faculty of Food Science and Technology, University of Agricultural Sciences \\ and Veterinary Medicine Cluj-Napoca, 400372 Cluj-Napoca, Romania; liana.salanta@usamvcluj.ro (L.C.S.); \\ carmen-rodica.pop@usamvcluj.ro (C.R.P.); maria.tofana@usamvcluj.ro (M.T.) \\ 2 Department of Food Engineering, Faculty of Food Science and Technology, University of Agricultural \\ Sciences and Veterinary Medicine Cluj-Napoca, 400372 Cluj-Napoca, Romania; \\ maria.socaci@usamvcluj.ro (M.V.I.); elena.mudura@usamvcluj.ro (E.M.); andrei.borsa@usamvcluj.ro (A.B.) \\ 3 Department of Soil, Plant and Food Sciences, University of Bari 'Aldo Moro', Via Amendola, \\ 165/A, 70126 Bari, Italy; antonella.pasqualone@uniba.it \\ 4 School of Food Science and Engineering, South China University of Technology, Guangzhou 510640, China; \\ hfzhao@scut.edu.cn \\ * Correspondence: teodora.coldea@usamvcluj.ro; Tel.: +40-264-596-384
}

Received: 13 October 2020; Accepted: 27 October 2020; Published: 30 October 2020

\begin{abstract}
Beer is the most consumed alcoholic beverage in the world and the third most popular beverage after water and tea. Emerging health-oriented lifestyle trends, demographics, stricter legislation, religious prohibitions, and consumers' preferences have led to a strong and steady growth of interest for non-alcoholic beers (NABs), low-alcohol beers (LABs), as well for craft beers (CBs). Conventional beer, as the worlds most consumed alcoholic beverage, recently gained more recognition also due to its potential functionality associated with the high content of phenolic antioxidants and low ethanol content. The increasing attention of consumers to health-issues linked to alcohol abuse urges breweries to expand the assortment of conventional beers through novel drinks concepts. The production of these beers employs several techniques that vary in performance, efficiency, and usability. Involved production technologies have been reviewed and evaluated in this paper in terms of efficiency and production costs, given the possibility that craft brewers might want to adapt them and finally introduce novel non-alcoholic drinks in the market.
\end{abstract}

Keywords: brewing; dealcoholization; non-alcoholic beer; craft beer; flavour

\section{Introduction}

Beer is one of the oldest fermented drink and most widely consumed alcoholic beverages in the world, produced 4th-millennium B.C. in the East, and later spread in ancient countries such as Egypt and Rome [1]. The brewing process can be divided into the following steps: Malting, milling, mashing, boiling, cooling, fermentation, maturation, filtration, carbonation, microbiological stabilization, and packaging. However, the advanced techniques have allowed brewers to produce beer in a more sophisticated and efficient way [2]. The huge popularity of beer arises from its pleasant sensory attributes and favorable nutritional characteristics as well as its lower cost, compared to other types of alcoholic beverages [2,3]. Also, beer gains interest due to the potential medicinal properties as a valuable source of vitamins, minerals, and antioxidants providing various health benefits [4]. Studies are suggesting that moderate beer consumption has significant effects on health, such as reducing the risk of cardiovascular disease, blood cholesterol level, diabetes, osteoporosis, dementia, 
and many others [5-8]. The potential health benefits of moderate beer consumption are restricted by the negative consequences of its alcohol and energy content [9]. However, there is potential to enhance the bioactive compounds of beer whilst reducing the alcohol and energy content through innovative brewing approaches, in terms of ingredients, brewing methods, and type of fermentation [10].

The production of beers with low alcohol content is a fast-growing segment in the global beer market [11]. Over the last few decades, multiple beer types and beer-like beverages have been developed worldwide, using different brewing process, technologies, and raw ingredients [12]. In Germany, a country with a vast tradition in beer production, according to the Reinheitsgebot, the sole ingredients used for obtaining beer are water, malted barley, hops (Humulus lupulus L.) and yeast [13,14]. The case is different in other countries, where laws governing beer production are less stringent and brewers have more flexibility. Wheat, rice, rye, oats, maize, unmalted barley, and to a lesser extent sorghum, millet, and cassava have all been used in brewing [15].

Thus, carbohydrate sources (adjuncts) like cereals (malted or unmalted) and sugar syrups are the most widely used, usually in conjunction with barley malt. Wheat and oat are commonly used as adjuncts due to their ability to promote foam stability, and before the use of hops, other bitter herbs (e.g., spruce twigs, pine needles and tree branches), spices, and flowers are added to spread different sensory profiles and to design special beers [16-20]. Moreover, from ancient times different fruits have also been used in brewing as sources of fermentable extract and as well as flavoring ingredients [12,15]. Fruits, wine, or honey are inoculated in the wort of beer due to their natural yeast sources. Perhaps given the global trend of wanting a healthier lifestyle and of improving product qualities, in the last decade the market of special beers has evolved significantly offering additional product traits such as enhanced functionality, new flavors, and tastes. These improvements went beyond the use of hops, which are nevertheless vital for the brewing industry [21], as they contribute significantly to the sensory properties of beer [22-24]. Lately, microbreweries are dedicated to the production of special beers, using fruits, honey, herbs, or spices to enhance the aroma and to provide flavors and colors that cannot be obtained from grains [25-27].

The brewers need to keep up with the consumers' interests and needs while designing novel beers [28]. Brewers have adapted to such demands with continuous improvements and attempts to minimize the alcohol content of their products while maintaining other characteristics [29]. Consumers are looking for products as close as possible to the conventional types, from a sensory point of view, especially in what regards flavor characteristics $[3,30]$.

A regular or conventional beer is an alcoholic beverage produced by the saccharification of starch and the fermentation of the resulting sugar. Beers can vary in alcohol content, bitterness, $\mathrm{pH}$, turbidity, color, and most importantly, flavor. Beers are distinguished mainly according to their visual appearance (color and turbidity) and fermentation process. Currently, a wide variety of beers are available and most of them belong to one of three groups: High (or top) fermentation, known as ale; low (or bottom) fermentation, known as lager; non-alcoholic-beers (NAB), which includes the low-alcohol beers $(<2.5 \%$, $v / v)$ and alcohol-free beers $(\leq 1 \% v / v)$ [31]. Low-alcohol beer (LAB), also known as "low alcoholic beer," "lower-alcohol beer," "low-point beer," "alcohol-reduced beer," and sometimes referred to as "light beer," has different definitions and the alcohol by volume limits depend on laws in different countries [29]. In Germany, the USA, and in China, this limit is no more than $0.5 \% v / v$; in Spain, the maximum value is $1 \% v / v$ alcohol; while in France, is of $1.2 \% v / v$ alcohol [32]. In Islamic countries such as Saudi Arabia and the United Arab Emirates, where alcohol consumption is prohibited by law, non-alcoholic beers (NABs) contain less than $0.5 \% v / v$ alcohol and represent an alternative to other non-alcoholic beverages because these provide some of the main bioactive components of traditional beer [33].

Over the past decade, there has been a global rise in the consumer interest in craft beers (CBs), particularly in traditional ales, and lagers, which are distinctively flavored, have a unique quality value and overall particular sensory properties [15]. Besides CBs are produced locally, in small quantities, are unpasteurized, unfiltered, and without added nitrogen or carbon dioxide pressure [34]. There are 
three major categories of brewers making $\mathrm{CB}$ and these are brewpubs, microbreweries, and regional craft breweries [35]. CBs are usually distributed regionally after they are produced in microbreweries following the basic brewing principles while using different adjuncts and yeast types, according to their consumers' preferences [36].

Nowadays, NABs are experiencing an unprecedented boom on the craft side of the market. This segment of no/low ABV beer has changed drastically and quickly mainly due to the consumer demand (sportives, mothers, drivers, etc.) and advanced technology to brew non-alcoholic beer. This review's purpose is to evaluate and discuss the production techniques of special beers such as NABs, LABs, and CBs focusing on the methods employed to improve their sensory characteristics appeal and to improve their popularity among consumers'.

\section{An Overview of Non-Alcoholic and Craft Beer}

\subsection{Market Landscape and Consumers Preference}

A beer's quality is measured by a complex set of sensory characteristics that include appearance, aroma, taste, and texture as it is an incredibly versatile beverage, served in various locations such as clubs, bars, and restaurants. Given this context, there will always be a high demand for beer, particularly from male consumers. The common aim to improve public health without spoiling consumers' enjoyment of certain beer types is an important matter for brewers and retailers [37]. Consumers are becoming ever more educated in what constitutes the appropriate flavor notes and "freshness" of beer [38], therefore there is a great challenge to try and reinvent certain beer types or to come up with completely new beer assortments. The future trends of beer production and products is best forecasted based on past statistics. As we can see, according to the European beer trends statistics report 2019 edition [39], in 2018, the top four beer producers of Europe consisted in Germany, with an overall beer production of 93,652 in $1000 \mathrm{HL}$, followed by Poland (42,603 in $1000 \mathrm{hL})$, United Kingdom $(42,282$ in $1000 \mathrm{hL})$, and Spain $(38,134$ in $1000 \mathrm{hL})$. Another report, the contribution made by beer to the European Economy [40], indicated that in 2018, more than 32 million hectoliters were exported from EU-28 countries outside the EU, which embodies over $8 \%$ of total production. This consists of large global brands, craft beers, and specialty brands made for export. It was also stated that there is increased investment in innovation, especially to produce new craft brews, expanding production lines to include cider and stout and to develop new beer flavors. Variety is looked for in all markets, therefore although conventional beer production is still heavily in the lead, craft beers, followed by specialty beers, alcohol-free, and low-alcohol beers, being so unique one to another would surely gain increased interest as time goes by. For example, the production of NAB (including malt beverages) increased in Germany from 5.4\% in 2012 to 7.3\% in 2018, while in Netherlands it went from 1.5\% in 2012 to $5.2 \%$ in 2018 [40]. Having this in mind, it is still thought that economies of scope can prevail over economies of scale, at least in what regards beer production. Moreover, it is supposed that standard ale and lager consumption will decrease as consumers progressively choose to drink 'Better, not more', getting out of the comfort zone and into the experiment area [41].

\subsubsection{Non-Alcoholic Beers: Alcohol-Free and Low-Alcohol Beers}

In the late twentieth century, the efforts of breweries to expand NAB assortments were driven mainly by the following goals: (1) to reach an increase in overall production by designing new products in countries with highly competitive markets; (2) to provide beer consumers with alternative products that can be consumed prior or during their daily activities (driving motor vehicles or operating machinery, practicing sports) or under certain conditions (pregnancy, medication) incompatible with alcohol consumption; (3) to enter beverage markets in countries where alcohol consumption is forbidden due to religious prohibitions. Although sales figures of beers having low alcohol content did not fulfill the initial optimistic expectations, today we are looking at a fast-growing segment of the beer market, worldwide [42]. Globally, NABs and LABs market experienced a total volume growth of $20 \%$ between 
2011 and 2016 and is forecasted to grow another 24\% until 2021. Middle East, Africa, and Western Europe are the biggest markets in terms of volume and value [29]. Particularly, German LAB market is one of the biggest in the world.

A consumer's perception of NAB quality is usually based on a complex combination of expectations, which are associated with the impact of some sensory properties such as color, foam, flavor and aroma, mouthfeel, and aftertaste $[36,43,44]$. Some of these sensory perceptions are out of the brewer's control, however in the case of those directly influenced by the brewing and packaging processes, beer flavor and aroma control are the most significant [44]. Factors that must meet consumers' demands include the appearance and flavor profile of each beer variety. Appearance can be influenced by impurities and might result in increased beer turbidity affecting the product's quality. Other important factors that influence the consumers' consumption habits are bitterness degree, alcohol content, along with the packaging's volume, design, and ease of transportation and storage [45]. Due to health and safety reasons, or to social regulations, the beer market is witnessing a significant rise in the consumption of $\mathrm{NAB}$, especially because it lacks the disadvantages associated with high alcohol contents. Globally, alcohol consumption is the third major health-risk factor with harmful consequences and serious social implications [46,47]. Thus, when considering the potential health benefits of beer, careful consideration should be given to novel brewing techniques and yeasts that could help to moderate or minimize alcohol content whilst optimizing the flavor and potential health effects $[10,48,49]$. The development of beverages that can influence consumers into more positive patterns of alcohol consumption is a challenge for all those involved in this industry [37]. Developing new beer products can deliver additional benefits (color, antioxidant properties, different taste, and smell), which could attract new customers, including not only existing consumers of beer but new non-beer-drinkers, as well [50]. Moreover, consumers are willing to spend more money on specialty beer, which normally has less alcoholic content compared to some beers and wines [51]. NAB consumers seek a product as close as possible to regular beer, but the dealcoholization processes give these beer types a different taste and overall sensory characteristics, which is sometimes reflected in modest consumer acceptance. LAB produced by limited fermentation is often characterized by a worthy off-flavor and sweet taste, which are not the usual common traits of beer. However, the slight separation from beer-like flavors towards a fruitier flavor might prove to be beneficial in terms of consumer acceptance [29].

Taste is a key factor in beverage choice given that through the tongue, compounds that impart taste can be sensed directly. The aroma, on the other hand, is linked to any volatile compound arising out of the beverage that can be perceived on the nose or retro-nasally, on the back of the mouth [43]. The main components associated with flavor are alcohols, phenols, esters, carbonyl compounds, and organic and fatty acids [52,53]. The marketing issues or labeling problems have been reviewed by Bellut and Arendt [29] and it was concluded that product labeling is a powerful tool for creating specific sensory expectations that can influence the consumer's choice.

Microbreweries usually lack a laboratory for quality control of beer [54]. From a technological point of view, it is a complex operation to maintain the taste profile of the NAB by removing alcohol [37]. Unfortunately, beer is exposed to chemical reactions starting with the moment it gets transported out of the production plant. Given the actual trend of big brewing producers to accede in global beer market, this involves longer time spans through which the product passes until it is consumed, contributing to an increasing risk over its quality. Malfliet et al. (2008) [55], distinguished as the most sensitive key marker constituents of flavor instability being trans-isohumulones, aldehydes (namely furfural, hexanal, 2-methyl-propanal, 2-methylbutanal, and 3-methylbutanal), proanthocyanidins, flavonoid content, and other physical parameters such as total bitterness, beer color, cold, and permanent haze formation.

The overall sensory experience of drinking a beverage is associated with different emotions. In the study conducted by Silva et al., 2016, beer is associated with positive emotional responses, such as "adventurous" and "energetic", while NAB evokes neutral and negative emotional responses, such as rational, conscious, and disappointed. This is because NAB is not treated as a different beverage, 
being instead perceived as a substitute for conventional beer. To secure success, some strategies to improve acceptability and image of NAB need to be adopted. In communication and advertisements, NAB should be associated with positive emotions for a higher level of congruency between expectation and experience [56], and it should be promoted for its already proven and potential benefits.

\subsubsection{Craft Beer}

Globalization has a decisive role in the evolution of the craft beer market, thereby the world is becoming a place of fast knowledge and information transfer. One of the results of globalization was the promotion of local traditions or specific local resources by creating and promoting beverages such as craft beers, which are diverse, atypical, and high-quality products [57]. There is not one recognized definition, still according to Brewers Association craft brewer is a small and independent brewer. The distinctive of craft beer and craft brewers is innovation by developing new types of beer. In the USA, a small brewery is the one, whose yearly production does not exceed $24,000 \mathrm{hL}$ and in Europe the production does not exceed 20,000 hL [58]. Consumers' rising interest in CBs began over the last years a trend known as "the craft beer revolution", which was first observed in the United States of America, around 1970 [59]. In the USA, in 2018, CB sales grew at a rate of $4 \%$ by volume, while in the UK, the Society of Independent Brewers Association reported an increase in craft beer production of $0.8 \%$ amongst its members [10]. In Europe, new and small craft breweries are making their appearance steadily and with great potential, since an annual increase of around $10 \%$ in microbreweries' revenue is expected until 2021 [60]. The European CB map is exemplified in three geographically and culturally related cases of Belgium and Germany that both have a rich, but distinct beer history and culture, and the Netherlands, where specialty beers are comparably a rather new, but still influential phenomenon. The Belgian consumer and tasting organization, Zythos, emphasizes that a company can only be called a "brewery" if they brew beer in their own facilities [61]. Craft beers are constantly increasing their market share, against the products of large multinational beer companies. This trend is influenced by several factors, such as: Per capita income growth, the availability of alternatives toward the production of high-quality beers, increased health concerns, and the emergence of new government regulations [62].

The development of craft brewing markets, however, was uneven in time and space [57]. Taking into consideration the number of new CBs available on the market every year, it is interesting to observe the "hyper-differentiation" phenomenon. The particularity of CBs is very appreciated by consumers and this lowers the importance of their prices, the main factor for choosing food and beverage [63]. According to the study conducted by Pokrivčák et al., 2019, consumers' choice for CBs are generated by a desire for more knowledge, new taste experiences, and an attitude against mainstream beer consumption [35].

Consumers seem to prefer CBs because they have a variety of flavors, such as notes of malted barley, chestnut, and honey, which might increase the probability of perceiving craft beers to be of a higher quality. Moreover, their consumption has become, in a qualitative approach, experienced-based and emerging from a desire for identity and distinction. CB consumption is perceived by consumers as an experience that offers pleasure, enjoyment, a sense of identity and belonging, self-fulfillment, social recognition, and sustainability [36]. Also, consumption of CB is perceived as an indication of social distinction and shows an affinity with a group united around this category of products [35]. The producers emphasize the typical and distinctive flavor of these products, due to the addition of fruits, herbs, and spices that can transform regular beer into specialty beer, together with other aroma ingredients and fermentable substrates [51,64]. Above all the ingredients mentioned, hops are without a doubt the most used and the driven force of most craft breweries. This ingredient has a crucial impact on beer quality. The hopping rate increased from $4.1 \mathrm{~g} \alpha / \mathrm{hL}$ (2010) to $4.3 \mathrm{~g} \alpha / \mathrm{hL}$ (2012) and it is expected to continue to increase due to the growing craft brewing sector [65]. Dry hopping is a technique that has been used by brewers to increase the hop aroma and flavor of beer for centuries. Throughout the 21st century, dry hopping has become an increasingly popular method among craft 
brewers to impart intense hoppy aroma and flavor to beer [66]. The dry-hopping procedure reported by Lafontaine and Shellhammer, 2018 lasted for $24 \mathrm{~h}$ at 13.3-15 ${ }^{\circ} \mathrm{C}$ with 200, 386, 800, and $1600 \mathrm{~g}$ hop/hL unhopped beer treatment rates. Both the aroma intensity and profile of beer were influenced by the number of hops added. Dry-hopping rates higher than $800 \mathrm{~g} / \mathrm{hL}$ contributed to the formation of aromas associated more with herbal/tea than citrus and is not recommended in terms of raw material efficiency using. The best results were obtained by the static dry-hopping rate of $400-800 \mathrm{~g} / \mathrm{hL}$. Most of the compounds that impact beer bitterness are extracted via the dry-hopping procedure where there is still hop materials left in the spent dry-hops. The authors, Lafontaine and Shellhammer, 2018, specified the importance of vessels volume and geometry as well as the beer-to-solids ratio within the vessel and hop particle settling velocity in the extraction of analytes responsible for the hoppy flavor. According to their study, the agitation is not recommended because it can impart herbal/grassy notes and extract polyphenols responsible of beer astringency [66]. The main compounds that influence the sensory properties of craft beers are organic acids, sugars, hop bitter acids, esters, terpenoids, polyphenols, and carbonyl compounds. Given this, the fermentation processes dictated by the inoculated yeasts are vital for the aromatic profile of the resulted beer [15].

\section{NAB and LAB Brewing Process}

The methods used for obtaining NAB or LAB have had a dynamic development in the last decades, in conjunction with the increase in market demand, driven by restrictive alcohol consumption policies in UE and the increasing awareness about the benefits of moderate beer drinking [56]. Although, until recently were implemented mostly in multinationals, requiring considerable investment in production and marketing, the present dynamics in the market allows the implementation of these methods even on a small scale. Thus, the technologies have been reviewed and evaluated in this paper in terms of efficiency and production costs, related to the possibility that craft brewers could adapt them, introduce them to a niche market, and quickly obtain return on investment. Generally, NAB or LAB beer production processes can be divided into two major groups, namely physical processes and biological processes. Physical processes can be based on thermal treatments or membrane separations.

\subsection{Techniques for Complete or Partial Alcohol Removal}

\subsubsection{Thermal Treatments}

The post-fermentation techniques focused on the complete or partial removal of the alcohol (ethanol) from the original beer by thermal treatments are falling film evaporation, continuous vacuum rectification, and thin layer evaporation (Figure 1).

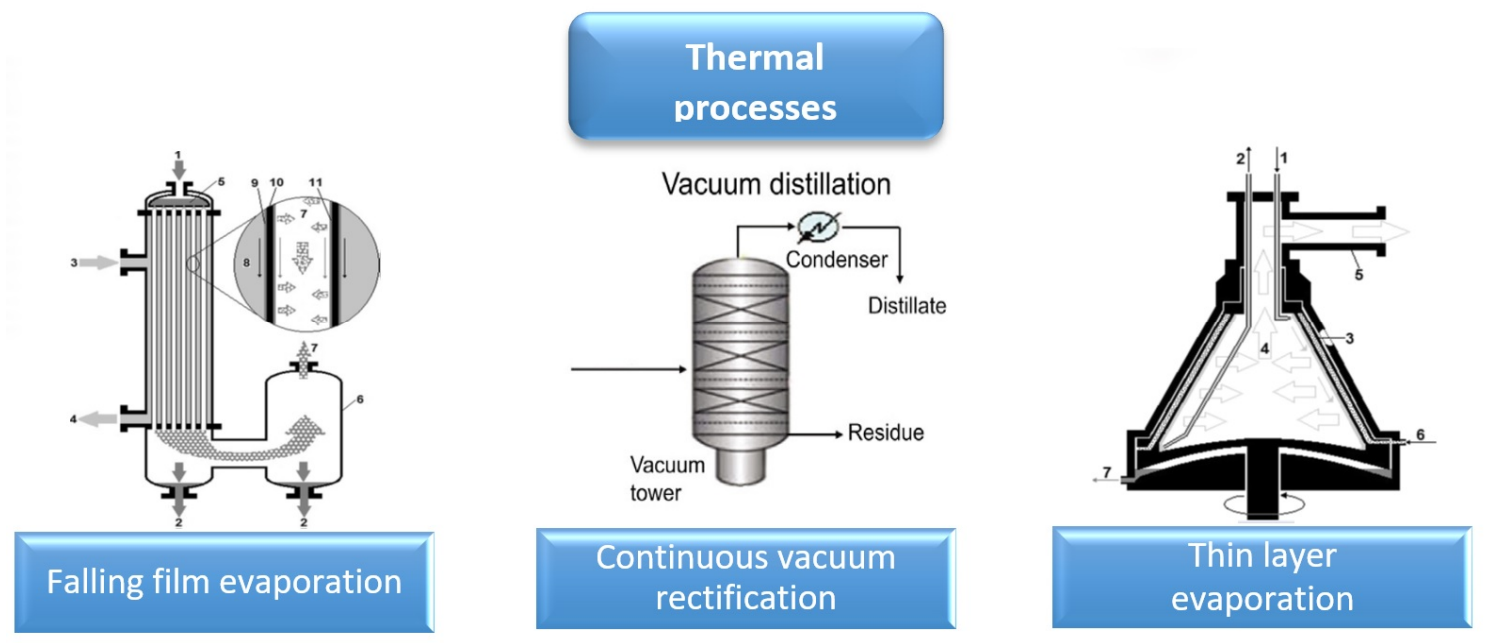

Figure 1. Graphical representation of thermal processes used to obtain non-alcoholic beer (NAB) and low-alcohol beer (LAB), adaptation from $[42,67]$. 


\subsubsection{Falling Film Evaporation}

The falling film evaporation consists in the following: The beer is pre-boiled under vacuum conditions, in an even thin film, enters the heating tubes through a distribution device in the head of the evaporator, flows downward at boiling temperature using gravity and co-current vapor flow and is partially evaporated. The process takes just a few seconds per pass. A vapor separator dissociates the alcohol-rich vapors from the dealcoholized beer concentrate, which are further condensed in a condenser. This technology is very accessible due low maintenance of the evaporator, as there are no moving parts and no wear, due to its high efficiency [68]. The main process parameters controlling the dealcoholization degree in the falling film evaporator are the heating steam supply and the evaporation temperature adjustable by the vacuum pump-control.

\subsubsection{Vacuum Rectification}

The technique consists in the following steps: The filtered beer is pre-heated in a heat exchanger, volatile compounds and $\mathrm{CO}_{2}$ are stripped in a vacuum degasser, and thereafter, in the vacuum column, the alcohol is released from the beer at $42-48^{\circ} \mathrm{C}$, recovering the aroma components from $\mathrm{CO}_{2}$ by spraying with dealcoholized beer or water, and redirecting them into dealcoholized beer [42]. This method offers a production capacity of $4-200 \mathrm{hL}$ of alcohol-free beer per hour with less than $0.05 \%$ ABV. Moreover, the alcohol vapors obtained as a by-product can be capitalized, per se, for vinegar production through acetification [33].

\subsubsection{Thin Layer Evaporation}

The centrifugal thin layer evaporator (Centritherm system or alternatively Spinning Cone Column) operates under vacuum conditions at low temperatures $\left(35-60^{\circ} \mathrm{C}\right)$ generated using steam and pressure from 60 to 200 mbar. The beverage enters the evaporator through a feed tube and injection nozzles, which distribute it to the underside of the hollow rotating cone. Centrifugal force instantaneously spreads the beer over the entire heating surface in an extremely thin layer (approximately $0.1 \mathrm{~mm}$ ). The beer passes across the heating surface in less than one second. The concentrated and dealcoholized beer collects at the outer edge of the cones and then exits the evaporator through a stationary product tube. The vapors removed from the beer rise through the center of the cone and enter an exhaust pipe that transfers them to an external condenser. The Centritherm evaporators are designed with 1-12 hollow cones, which correspond to production capacities of NAB from 0.5 to $100 \mathrm{hL} / \mathrm{h}$, respectively, allowing the production of beer having an alcohol content below $0.05 \% v / v$ when a rectifying column is coupled to the evaporator [33,42]. The disadvantages of this process are the high energy costs and the need to install an additional evaporator in the plant. The advantages and disadvantages of the main thermal processes are presented in Table 1.

Table 1. Comparison of capacity output, equipment needed, and advantages/disadvantages of the main thermal processes used in NAB and LAB production $[42,67,69]$.

\begin{tabular}{|c|c|c|c|}
\hline & Capacity & Extra Set Up Needed & Advantages/Disadvantages \\
\hline Falling film evaporator & $1-150 \mathrm{hL} / \mathrm{h}$ & $\begin{array}{l}\text { - evaporator column } \\
\text { - vapor separator } \\
\text { - vapor condenser } \\
\text { - rectifying column for } \\
\text { flavor compounds } \\
\text { recovery (optional) }\end{array}$ & $\begin{array}{l}\text { + low acquisition and operation } \\
\text { cost, high efficiency, easy to } \\
\text { construct and easy to clean. } \\
\text { - final product with considerable } \\
\text { losses of flavor compounds }\end{array}$ \\
\hline Vacuum Rectification & $4-200 \mathrm{hL} / \mathrm{h}$ & $\begin{array}{l}\text { - heat plate exchanger } \\
\text { - vacuum degasser } \\
\text { - rectifying column } \\
\text { cooler }\end{array}$ & $\begin{array}{l}\text { - sensory properties of NABs are } \\
\text { significantly changed, high energy } \\
\text { requirements }\end{array}$ \\
\hline Thin layer Evaporation Centritherm & $0.5-100 \mathrm{hL} / \mathrm{h}$ & $\begin{array}{l}\text { - centrifugal evaporator } \\
\text { - external Condenser for } \\
\text { volatile compounds }\end{array}$ & $\begin{array}{l}\text { + easy to operate, service-friendly } \\
\text { and hygienic } \\
\text { - high maintenance expenditure, } \\
\text { high energy requirements }\end{array}$ \\
\hline
\end{tabular}




\subsection{Membrane Separation Processes}

Membrane separation processes (Figure 2) can be broken down into nanofiltration, reverse osmosis, osmotic distillation, dialysis, and pervaporation. They offer some competitive advantages compared to other physical NAB production processes like mild operational temperatures, low energy consumption, little or no need for using enhancing agents, reduced operating costs [70], but still additional equipment from existing is required apart from the standard industrial plants.

\section{Membrane-based}
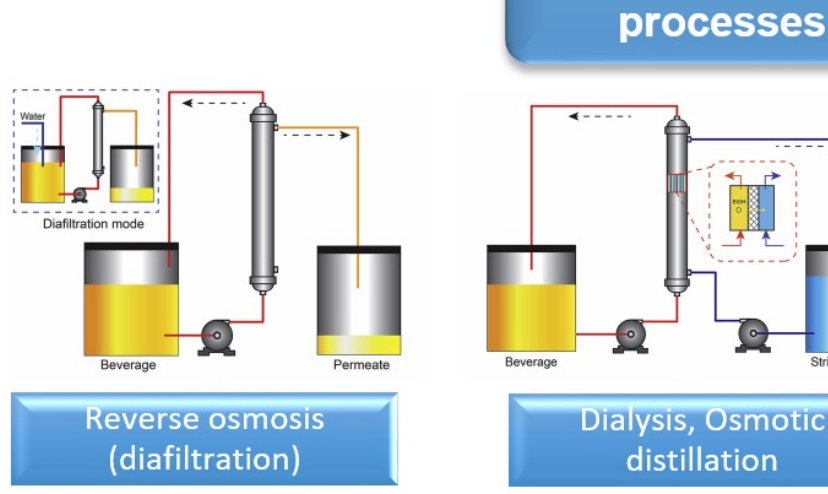

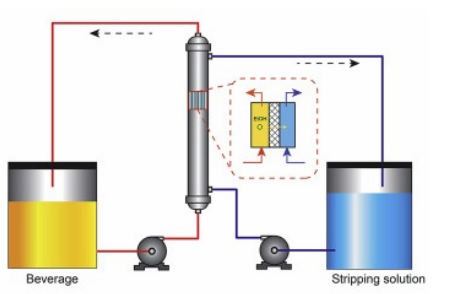

Dialysis, Osmotic distillation

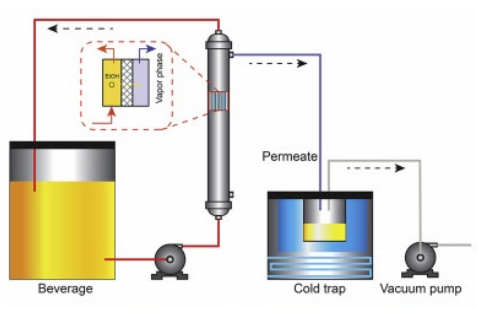

Pervaporation

Figure 2. Graphical representation of membrane-based processes used to obtain NAB, adaptation from [69].

\subsubsection{Reverse Osmosis}

The reverse osmosis $(\mathrm{RO})$ process requires that the filtered beer flows tangential to the membrane surface, and ethanol and water permeates the membrane selectively when the transmembrane pressure substantially exceeds the osmotic pressure of beer [67]. The process unfolds in three stages: The concentration phase, when the permeate, consisting of alcohol, water, $\mathrm{CO}_{2}$, and aromatic substances, is removed from the beer, increasing the alcohol until desired concentration; the diafiltration phase, when demineralized water quantitatively replaces the permeate previously removed; the make-up phase, when demineralized water refills the retentate to the initial volume of beer, further lowering the alcohol content. Due to the $\mathrm{RO}$ and the $\mathrm{CO}_{2}$ removal during process, carbonation of the final product is required [68]. According to Catarino et al. (2007), large molecules, such as aromatic compounds, will mostly remain at the retentate side of the membrane, even when utilizing low temperature and high pressure [71]. Research shows that the reverse osmosis is not economically feasible for the production of beer with an alcohol percentage less than $0.45 \%$ [72].

\subsubsection{Dialysis}

In obtaining NABs through a dialysis process, a semipermeable membrane separates beer and dialysate (aqueous solution), which flow in countercurrent, the exchange of substances occurring practically only by means of diffusion [73]. The contact time and the concentration gradient at the membrane determines compound exchange degree. Although resembling the $\mathrm{RO}$, in the dialysis method, there is no concentration stage, there is no post-carbonation of the NABs needed [68], and no required high-pressure pump, generating lower operational costs.

\subsubsection{Osmotic Distillation}

Osmotic distillation is a beer dealcoholization process carried out at low pressure and temperature, with low interaction between the membrane and the permeate and retentate, a method that has a high energy efficiency compared to RO or distillation [74]. The downside of the process is that the volatile compounds $\mathrm{CO}_{2}$ are lost in the process thus it requires additional investment in a recovery 
unit [73]. The selectivity of the process is determined by the equilibrium between the liquid and vapor concentration in the system, since the component that presents the highest partial pressure suffers the highest permeation rate of the membrane [74].

\subsubsection{Pervaporation}

The pervaporation process utilizes selective semipermeable membranes to separate alcohol through diffusion in its gas phase at low temperatures. The difference in chemical potential of the separated fluids generate displacement of alcohol molecules and permeate the membrane in the direction from the highest alcoholic concentration to the lowest [33].

Aside from beer dealcoholization, the pervaporation technology can also be used to extract and concentrate volatile aroma compounds from beer, by manipulating the temperature and suitability of the membrane constituents accordingly [75,76], and subsequently add them to the final NABs [70].

The literature presents other methods researched in lab scale conditions like supercritical $\mathrm{CO}_{2}$ extraction [42], nano filtration [77], absorption on hydrophobic zeolites [42], and freeze concentration [68], but without current advances of technology and craft beer NAB appliances. The main advantages and disadvantages of membrane processes used in NAB production are presented in Table 2.

Table 2. Comparison of pressure/temperature output, equipment needed, and advantages/disadvantages of the main membrane processes used in NAB production $[67,74,75]$.

\begin{tabular}{|c|c|c|c|}
\hline & Pressure/Temperature & Extra Set Up Needed & Advantages/Disadvantages \\
\hline Reverse Osmosis & $\begin{array}{c}10-60 \text { bar } \\
5-20{ }^{\circ} \mathrm{C}\end{array}$ & $\begin{array}{l}\text { - reverse osmosis equipment } \\
\text { - carbonation equipment } \\
\text { - high-pressure pump } \\
\text { cooling system }\end{array}$ & $\begin{array}{l}\text { - high energy consumption, low flux rate, } \\
\text { high pressure requirement, significant } \\
\text { losses of volatiles } \\
\text { + lower costs than that of a conventional } \\
\text { distillation system }\end{array}$ \\
\hline Dialysis & $\begin{array}{l}10-60 \text { bar } \\
\left(1-6^{\circ} \mathrm{C}\right)\end{array}$ & $\begin{array}{l}\text { - dialysis equipment } \\
\text { cooling system }\end{array}$ & $\begin{array}{l}\text { + low operational costs and very low } \\
\text { working temperatures } \\
\text { - lack of body in the final product }\end{array}$ \\
\hline Osmotic Distillation & $\begin{array}{l}20-80 \text { bar } \\
5-20{ }^{\circ} \mathrm{C}\end{array}$ & $\begin{array}{l}\text { - osmotic distillation equipment } \\
\text { - volatile compounds recovery unit } \\
\text { - high-pressure pump }\end{array}$ & $\begin{array}{l}\text { + higher energy efficiency than RO or } \\
\text { distillation } \\
\text { - depletion of main volatile compounds } \\
\text { than RO }\end{array}$ \\
\hline Pervaporation & $\begin{array}{c}1 \mathrm{bar} \\
10-20{ }^{\circ} \mathrm{C}\end{array}$ & $\begin{array}{l}\text { - pervaporation equipment } \\
\text { - separate beer dealcoholisation unit }\end{array}$ & $\begin{array}{l}+ \text { the most effective membrane process } \\
\text { for the recovery of aroma compounds in } \\
\text { beverages } \\
\text { - partial ethanol removal }\end{array}$ \\
\hline
\end{tabular}

\subsection{Biological Processes}

The biological methods (Figure 3) of the NAB production based on limited alcohol formation can be divided according to the production equipment they require, such as traditional brewery equipment requirements (changed mashing process, arrested or limited fermentation process, cold contact process, and utilization of special yeast) or use of special equipment (continuous limited fermentation). Clearly, the most exploited technologies by beer crafters and large-scale industrials are those that do not require further investments as often combinations of strategies are used, while the continuous immobilized cell process is a promising but niche technology. 


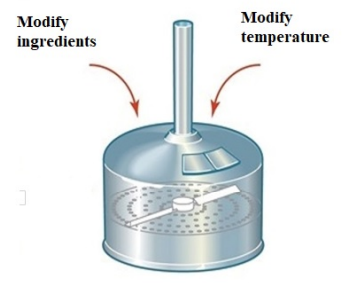

mash mixer

Changed mashing process

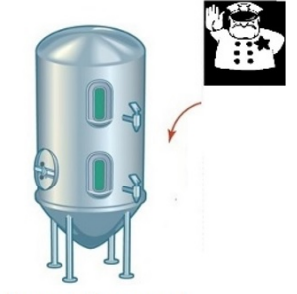

fermentation vessel

Arrested or limited fermentation process
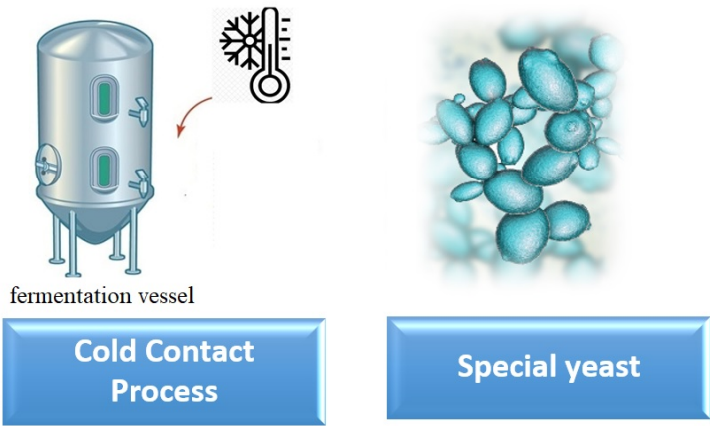

Figure 3. Graphical representation of membrane-based processes used to obtain NAB (Compilation from Encyclopedia Britannica's brewing process).

\subsubsection{Changed Mashing Process}

The fermentative potential of the wort, accounted for by fermentable sugars, will determine the potential alcohol content in beer. By changing the mashing process, consequently, the profile of wort sugars can be changed to further limit the alcohol formation. A wort fermentability of about $25-30 \%$ is needed to produce a low-alcohol beer [78]. Thus, a wort with a low fermentable sugar content can be attained by following strategies such as: (1) Inactivation of $\beta$-amylase enzyme, which is sensible to a higher mashing temperature $\left(>75^{\circ} \mathrm{C}\right)$; (2) cold water malt extraction obtaining wort with some fermentable sugars; (3) reducing the fermentable extract/unfermentable extract ratio by adding other grains such as maize or rice to barley; (4) re-mashing of spent grains to produce a second extract with very small amounts of fermentable sugars. Two modifications of the original method are known: (a) Extrusion cooking of the spent grains prior to the second extraction and (b) acidic hydrolysis of spent grain to yield a secondary wort with a significant content of non-fermentable pentoses $[42,68,70]$; (5) use of barley varieties with $\beta$-amylase deficient with wide variations of b-amylase thermostability [3,73]. These processes will generate a higher quantity of nonfermentable sugars residue in the wort and subsequently unpleasant sweetness in the NABs, higher risk of microbial contamination, and a wort-like flavor. For ensuring successful beer production, mixed corrective measures are necessary, and these include vigorous wort boiling for lowering the level of aldehydes, wort acidification, limited fermentation, and color and bitterness adjustments.

\subsubsection{Arrested or Limited Fermentation Process}

This approach is perhaps the most popular way to produce NAB and LAB. Arrested or limited fermentation processes are focused on keeping a low ethanol content by removing yeast after a partial fermentation (stopped fermentation through filtration or centrifugation) or by creating conditions to inhibit the yeasts activity (limited fermentation through rapid cooling to $0{ }^{\circ} \mathrm{C}$, pasteurization) at the same time restricting or disabling the wort-like flavor impression. These production methods operate with the same equipment available in a traditional brewery, but they require accurate and swift analytical control [32,42]. The disadvantages of these methods are triggered by the fact that limited fermentation time and inadequate conversion of wort to beer might result in a final product deficient in aromatic compounds but with a powerful wort characteristic [33,79]. Researches show that for both arrested or limited fermentation processes, an initial gravity from 4.0 to $7.5 \mathrm{wt}$. \% is favorable and that brewing at high gravity $(20 \mathrm{wt} \%)$ enhances the formation of higher alcohols and esters. Further sensorial corrections of volatiles can be accomplished by: (1) Fermenting at a higher temperature; (2) inhibiting wort's oxygen content, which increases significantly the ester formation by ale yeasts [68]; or (3) the addition of flavorings (e.g., isoamyl acetate) to cover the "defects" [43]. 


\subsubsection{Cold Contact Process}

This method can be easily adopted because it uses the same equipment as traditional beer fermentation. The so-called "cold contact process" uses low-temperature $\left(0-5{ }^{\circ} \mathrm{C}\right)$ fermentation [68]. The yeast's primary metabolism is decelerated reducing carbonyl compounds and ethanol production. The amino acids are converted into aldehydes, which concur to the formation of off-flavors. The cold-fermented NABs have characteristics like those of common beer [3].

\subsubsection{Utilization of Special Yeast}

This method of NAB production is associated with two different approaches: One based on the selection of specific strains and the other on genetic modifications of brewing yeast. Specific strains of the genus Saccharomyces and Saccharomycodes are incapable to ferment maltose; the main sugars in the wort, however, are able to ferment fructose and sucrose, generating a lower ethanol content but a high residual extract content and a high proportion of glycerol and sugar alcohols [3]. Zygosaccharomyces rouxii offers limited application for NABs since it requires oxygenation of beer to consume ethanol under aerobic conditions and has negative effects on the flavor and colloidal stability [42]. The use of $S$. ludwigii for NABs generates better results than the latter, offering sweet notes from the high residual maltose and maltotriose. Like Saccharomyces cerevisiae, it is unable to ferment the latter and it produces liveliness and fullness in beer with higher alcohol and ester formation, with barely perceptible worty off-flavor. The genetic approach is not yet largely accepted by the consumers and consequently craft brewers will not risk and implement it in their breweries.

\subsubsection{Continuous Fermentation}

This process consists of the use of yeasts attached to a carrier material, such as diethylaminoethyl cellulose (DEAE-C), calcium alginate, calcium pectate, or sintered glass. The carrier material and the yeast are placed in a reactor, where the wort flows and generates increased biomass concentration and accelerated transformation of wort into beer [33]. In a brewery, this process could generate advantages consisting of lower capital, production, and manpower costs, although investment is required in immobilization support, low temperatures $\left(2-4{ }^{\circ} \mathrm{C}\right)$ for limiting yeasts' growth and metabolism, and anaerobic conditions for preventing an oxidation phenomenon responsible of off flavor development. Different technologies for immobilization exist, as reported by Montanari et al. 2009, but are adapted to regular beers and are improbable to be applied in craft brewers due to the difficulty to control the process parameters (e.g., temperature, concentration of dissolved oxygen) for producing NABs [68].

Both alcoholic and non-alcoholic beers contain residual fermentable sugars that are highly susceptible to spoilage organisms. Good production hygiene is important for the microbiological stability and safety of the beverages [48], but in order to ensure them, the craft brewers have at their disposal multiple physical and biological solutions. The physical techniques include traditional techniques like thermal processing, filtrations and use of weak organic acids (sorbates, benzoates, sulphites), and emerging non-thermal preservation techniques like high-pressure processing, hydrodynamic cavitation, ionizing irradiation, pulsed high-voltage electric field, and ultraviolet irradiation treatments. Biological techniques, mainly used to obtain more "natural" products, include preservation with natural antimicrobials obtained from herbs, spices and their derived essential oils and extracts, or bio-acidification of wort with selected microbes showing good antimicrobial properties [80].

\section{Strengths and Weaknesses of Alcohol Removal Techniques}

Craft brewers have several options available to obtain a new recipe for NAB or LAB and develop their portfolio on a growing market segment. As presented in Table 1, the most important factors that affect craft brewers' decisions revolve around the necessary investment and the final product quality. 
The thermal methods could be used to produce a LAB with up to $0.05 \%$ alcohol, increased output, and low operation costs but will require a high investment and will generate significant volatile compounds loss and some thermal stress on the beer inducing oxidation reactions.

The membrane separation processes are the most advanced in the industry available for alcohol free beer production and offer better advantages than the thermal methods regarding the final product's flavor and the possibility to reincorporate extracted beer volatiles. However, these processes have the drawback of having a high investment and operational cost.

Most biological processes have the advantage of using the same equipment from the traditional beer fermentation, therefore are easy to adapt them to the regular processes. Although the beers produced will have a sweet and worty taste, this can be turned into an advantage by brewers by developing beers with different flavors for millennials or can be improved with different technological additives. Brewing experience is necessary to control the processes since well-equipped control laboratories are rarely found in this niche. The investment in immobilized yeast reactor is not likely to be adopted due to the high output required to generate profit, which is not characteristic of craft brewers. In Table 3 are presented the main processes used in LAB production.

Table 3. Comparison of necessary investment and operational costs of the main processes used in LAB production, adaption after [33].

\begin{tabular}{cccc}
\hline PROCESS & INSTALLATION COSTS & OPERATIONAL COSTS & BEER QUALITY \\
\hline BIOLOGICAL PROCESSES & & & \\
Changed mashing process & $\$$ & $\$ \$$ & 0 \\
Cold Yeast Contact & $\$$ & $\$ \$$ & 0 \\
Special yeast & $\$$ & $\$ \$$ & 0 \\
Immobilized Yeast & $\$ \$$ & $\$$ & 0 \\
THERMAL PROCESSES & $\$ \$ \$$ & $\$$ & 0 \\
Thin layer Evaporation & $\$ \$ \$$ & $\$ \$$ & 0 \\
Vacuum Rectification & $\$ \$$ & & 0 \\
Falling film evaporator & $\$ \$$ & $\$$ & 0 \\
MEMBRANE PROCESSES & $\$ \$$ & $\$$ & 0 \\
Reverse Osmosis & $\$ \$$ & $\$$ & 0 \\
Osmotic Distillation & $\$ \$$ & $\$$ & 0 \\
Dialysis & Pervaporation & & 0
\end{tabular}

\section{New Trends Regarding Yeasts Involved in Fermentation of Special Beers}

Beer is a perishable product and many factors can diminish a beer's quality from the time it is brewed to the point of consumption. In the brewing process, the efficiency of fermentation and the character and quality of the final product are intimately linked [81]. The lactic acid bacteria are known as the most frequent bacteria found in beer, accounting for $60-70 \%$ of all spoilage incidents. Except some specific strains of lactic acid bacteria, which are found in some special beers, namely the "sour beers" (Flanders Red Ale, Framboise, Kriek, the latest two also known as fruit Lambic beers), they are considered the spoilage bacteria in beer, which causes off-flavor development, which is mainly attributed to the formation of lactic acid and diacetyl $[48,82,83]$. The fermentation processes applied to foods and beverages in various technologies and operations are used to convert perishable and indigestible raw materials into pleasant foods and drinkable beverages with added value and high stability [84].

Beer, as a fermented beverage, is based on microbial metabolism for production. Saccharomyces cerevisiae is the dominant species, that is used in the production of alcoholic beverages worldwide. The strains of this species employed in fermentation exert a profound influence on the flavor and aroma characteristics of the resulted beverages [85]. Traditionally, strains of Saccharomyces cerevisiae 
and Saccharomyces pastorianus (synonym Saccharomyces carlsbergensis) are the two species widely used as starter cultures for the production of the two most categories of industrial beer, which are 'ale' and 'lager' beers, strains known as the top-fermenting and bottom-fermenting yeasts $[49,86]$. A perfect model of an organism may be considered Saccharomyces cerevisiae. Its short replication time, simple cultivation, sporulation efficiency, rare pathogenicity, and small genome size have made it an ideal research organism and placed it at the front of many scientific advances [87]. These strains of yeasts have become dominant, especially Saccharomyces cerevisiae, due to their alcohol tolerance and rapid fermentation rates, which are ideal for commercial beer production [10]. The current approaches have led to the exploration of various yeasts in the brewing process. This, akin to many of the developments in modern beer production, special beer production is largely driven by commercial reasons and for improving the product's biological properties $[10,15]$.

In this context, Saccharomyces boulardii is a new type of yeast, that acts as a probiotic yeast and tends to produce less alcohol. The probiotic yeast Saccharomyces boulardii is capable of fermenting brewery wort and optimizing the process variables led to improved production of volatile compounds by this yeast. The obtained product has similar sensory qualities with the traditional product, high commercial characteristics, and lower value of $\mathrm{pH}$, which helps to maintain the beer's shelf life [88]. It has also been described by Mulero-Cerezo et al. (2019) that Saccharomyces boulardii show higher viability during the fermentation process, which is ideal for producing a craft beer containing viable probiotic cells [34]. Several studies demonstrated that Saccharomyces boulardii can generate bioactive compounds in fermented beverages thus improving their functionality $[89,90]$. Other strains, such as Saccharomycodes ludwigii, Zygosaccharomyces rouxii [10], Torulaspora delbrueckii, Pichia kluyveri [49], Lachancea thermotolerans [91], and Brettanomyces spp. [92], have been assessed as candidates, producing a beer that is acceptable to consumers, commercially viable, and low in alcohol.

The new trend in brewing biotechnologies involves non-Saccharomyces yeasts in the fermentation process given the improvements they can produce in sensory quality and differentiation, especially in craft beers and low-alcohol beers [62]. For example, Brettanomyces spp. are essential in the production of lambic-style beers [86], where they contribute with flavors that are not normally produced by Saccharomyces spp. Often, Brettanomyces spp. can produce smoky, barnyard, spicy, and medicinal flavors in beverages [87]. On the other hand, Brettanomyces can produce $\beta$-glucosidase, an enzyme responsible for the hydrolysis of glycosides, commonly found in the hop and other sources. Therefore, this could increase or modify the hop aroma due to the numerous released monoterpenes, which are the key aroma substances from hop [86].

Lachancea thermotolerans is a yeast that can be used successfully in the making of craft beers because of its ability to ferment until $4-9 \% v / v$ producing high amounts of lactic acid from sugars and interesting effects in beer aroma. It is also a good candidate due to the natural biological acidification during the fermentation process [62]. Interestingly, Lachancea thermotolerans also can produce lactic acid, which can affect both flavor and mouthfeel. The beers obtained at the lower fermentation temperature $\left(14^{\circ} \mathrm{C}\right)$ are associated with sensory-related words such as fruity, floral, sour, clove, melon, and strawberry [91]. Moreover, the ability to produce significant amounts of lactic acid make that strain suitable to be used in the production of acidic beers without the involvement of lactic bacteria [62]. Studies conducted by Zdaniewicz et al. (2020) confirmed that the Lachancea thermotolerans strains can produce lower alcohol as compared to Saccharomyces cerevisiae strains [93].

Torulaspora delbrueckii is another versatile yeast suitable for beer production [62], as it exhibits low alcohol production ability [94] due to its inability to utilize maltose [95]. This strain has the added advantage of being resistant to the various stress factors encountered during brewing [87] and to produce 2-phenyl ethyl acetate, a floral ester with positive floral aroma, that increases during fermentation [62]. Canonico et al. (2016) reported that the beers obtained with Torulaspora delbrueckii were characterized by a good aromatic profile and a low alcohol content $(2.66 \% v / v)$ [96]. Following other studies $[95,96]$, this yeast was found to be suitable for brewing applications. 
Pichia kluyveri strain can be used for producing NAB or LAB owing to its limited ability to ferment glucose whilst significantly changing hop compounds into positive flavor compounds $[57,97]$. Pichia kluyveri produces much less diacetyl compared with the Saccharomyces cerevisiae brewers' yeast strain. Also, the production of desirable ester compounds is high and leads to a lower production of unwanted acids such as octanoic acid and decanoic acid [95].

Zygosaccharomyces rouxii is the most xerotolerant yeast; this high osmotic tolerance could potentially be used in high gravity brewing since some strains have shown to ferment all wort sugars [97]. This yeast strain is also considered suitable for producing fermented beverages with low alcohol content because of its total or partial inability to ferment maltose [49]. After a fermentation process with Zygosaccharomyces rouxii, esters and higher alcohols are the main flavor-active compounds identified in beer [95].

\section{Compounds Involved in Special Beers' Stability and Quality}

\subsection{Impact of Polyphenols on Beer Flavor Stability}

Over the past years, many beer endogenous antioxidants, such as phenolic compounds and Maillard reaction products, were reported as responsible for beer flavor stability. Of these, phenolic compounds are considered as the most important due to their potential health benefits [98-101] and their implications in beer processing. The greatest quantity of phenols comes from malt, $80 \%$, and the difference, from hops. Additionally, malt characteristics (variety, malting process) and beer technology (mashing, fermentation, and conditioning) significantly influence the antioxidant activity of final beer [102], its enrichment in polyphenols, and also its flavor stability [103]. Recent findings [104] proved that optimizing the specific mashing parameters (temperature, rest duration for some enzymes during saccharification) could improve the phenols content and the wort antioxidant activity. Specific malt varieties were identified as having high total phenols content and antioxidant activity, which can be used to optimize the flavor stability of beer. The same study [103] indicated that adjusting malting and mashing parameters (increasing the kilning temperature, prolonging the protein rest, and saccharification rest time) is essential for increasing the levels of phenolic compounds and antioxidant activity of worts, which will positively impact beer's quality.

During maturation, beer composition is enriched in volatile compounds, but when stored, some unwanted compounds are inevitably formed. These beer aging products differ depending on the various beer types, lager beer being reported as the most sensitive [105]. Given this, it is impossible to establish some specific storage parameters. The overall beer aging results in decreasing the bitter taste, increasing the sweet one, and the formation of unwanted volatile beer aging markers [106]. The final beer's content of phenols is related to the beer process applied and the raw materials being used. Some phenolic compounds are of particular interest because they may influence sensory attributes like flavor, foam, color, and colloidal stability. Despite the association of polyphenols with turbidity, they present a special capacity to improve the oxidative and flavor stability. During beer processing, important amounts of phenols are lost through trub separation, by their adhesion to yeast cells during fermentation, by elimination during beer conditioning, and by their overall decreasing trend during storage. Some polyphenols contribute to beer bitterness, therefore, being important compounds overall, new methods are necessary to retain and reintegrate them in beer using perhaps extracts able to positively fulfil beer's flavor and taste.

\subsection{Prenylflavonoids}

Prenylflavonoids are contained in hops and are recognized for their various benefits (antioxidant, anticarcinogen, antimicrobial, estrogenic, efficient in osteoporosis, anti-inflammatory, antiviral) over human health in the context of moderate beer consumption [99]. In what regards the effect on beer quality, prenylflavonoids possess antioxidant activity, and ensure foam stability, adding to the prolonging of microbial and flavor stability during storage. In our previous studies, we presented the methods through which these compounds can be efficiently capitalized in beer [107-109]. 
Still, large amounts of prenylflavonoids are removed throughout the process, as the brewery's by-products. The amount of prenylflavonoids found in brewers spent hops (discharged through hot trub-0.2-0.4 kg/hL beer) varies depending on multiple factors such as raw material quality, dosage in wort, wort composition, and boiling parameters. During alcoholic fermentation and beer conditioning, the concentration in prenylflavonoids is considerably reduced due to their adherence on yeast's cell walls. Spent yeast represents the second by-product of brewing industry $(1.5-3 \mathrm{~kg} / \mathrm{hL}$ beer).

\subsection{Beer Color}

One of the main aspects related to beer stability during storage is beer's tendency of changing color. Malfliet et al. 2008 [55] found that beer changes color especially in the first 60 days of storage at $30{ }^{\circ} \mathrm{C}$, with a similar color change also resulting after a nine-month interval of storage at $22^{\circ} \mathrm{C}$, a similarity that suggests the importance of storing temperature to beer color. Another study conducted by Cao et al., 2011 [110], discovered an almost linear increase of beer color during storage at room temperature, explained by the formation of Maillard reaction products and oxidative degradation of polyphenols during the pasteurization process [110]. In terms of special beers colors adjustment, the melanoidin malt addition plays the role of a coloring agent of pale lager beer and positively enhances the beer flavor stability $[15,111]$. Storage without oxygen and at low temperature is recommended so as to minimize the synthesis of pigments [112]. Moreover, in the study conducted by Callemien and Collin, 2007, for the beer samples, it has been shown the impact of catechin in the color increasing through storage.

\subsection{Haze Stability}

Phenolic compounds play an important role in beer's quality and in its haze stability, with catechin and epicatechin being involved in both haze formation and beer colloidal stability. Almost $80 \%$ of catechins originate from malt, the rest come from hops. Catechins are involved in beer stability due to their affinity to proteins therefore obtaining optimal concentration of catechins becomes essential. Brown beer represents a rich source of catechins (46.4 mg CE/100 mL [101], 14.1-37.5 mg/100 mL [113]. Moreover, it is important to take note of the fact that catechins and epicatechins are also involved in the beer's bitter taste [101]. The studies of McMurrough et al., 1992, 1996, have revealed that flavonoid dimers are also important for haze formation [114,115].

\subsection{Protein in Beer-Influence on Beer Flavor Stability}

Nitrogenous compounds are the second major class of nutrients after carbohydrates. Malt provides simple nitrogen sources for the yeast, such as aminoacids. Besides aminoacids, wort contains ammonium and some di- and tripeptides. Almost the entire free amino nitrogen (FAN) content of wort is used by yeast for their growth. The level of FAN strongly influences the content of higher alcohols, ester vicinal diketones, and hydrogen sulfide formation owing to the function of amino acid metabolism in the formation of these flavor compounds. Unfortunately, high temperatures and high dissolved oxygen concentrations contribute to a high FAN utilization, finally leading to flavor imbalances [116].

\section{Beer Enhancements and New Special Beer Designs}

It was shown so far that beer encompasses carbohydrates, nitrogen compounds, phenolic compounds, ethanol, vitamins, lipids and melanoidins, volatile compounds, antioxidants, flavors, aroma inducers, and emulsion stabilizers [117]. As discussed in the previous chapters, there is an increased interest in reinventing conventional beer to make it more attractive.

Beers can be redesigned by using alternative ingredients or by adding other foods to the original ingredients list. Such examples are commercially available Italian ale style beers made by adding, throughout the fermentation process, natural foods such as chestnut, cocoa, coffee, green tea, honey, liquorice, and walnut. The resulted products had their nutritional values assessed in comparison with regular beers. It was concluded that most of the studied special beers (4.5\%-9.0\% ABV) possessed 
considerably higher antioxidant activity, total polyphenols, and flavonoids contents than the five conventional beers $(4.6 \%-6.6 \% \mathrm{ABV})$ included in the study. Most of those reinvented beers were enriched with catechin, epicatechin, rutin, myricetin, quercetin, and resveratrol. Moreover, enhanced contents of phenolic acids such as ferulic, p-coumaric, syringic, and sinapic acids were found in the reinvented beers as compared with regular ones. This indicated that adding natural foods during the fermentation process resulted in the production of beers with improved antioxidant activity and superior phenolics profile [118]. Moreover, beers rich in phenolic antioxidants exhibits higher quality, more stable flavor and aroma, foam stability, and longer shelf life with respect to beers with lower antioxidant activity.

A study emerged at the beginning of 2020 regarding fruity beers (5-8\% ABV), mainly beers produced by adding apple, apricot, cherry, grape, orange, peach, plum, or raspberry to the fermentation process. The studied samples of such industrially produced assortments were assessed as having an increased antioxidant activity and a quantitatively augmented phenolics profile. Compared to conventional beers $(4.8-7.0 \%)$, the content of phenolic acids such as chlorogenic, neochlorogenic, p-coumaric, and caffeic acids, was higher in fruity beers. Beers obtained using cherries showed the highest overall values, followed by the ones obtained with the addition of grape, plum, and orange [119].

As previously mentioned, fruit-infused beers such as those obtained by adding Aronia berries during the fermentation process have increased polyphenol content and antioxidative capacity [120]. Another study focused on the production of special fruit ale beers $(3.6-5.63 \% \mathrm{ABV})$ with different concentrations of barley malt and persimmon juice, from the 'Rojo Brillante' variety. The resultant beers met the quality standards of regular beers and were rich in citric and lactic acid [13].

Another study investigated how the addition of propolis to a craft beer brings a potential increase in bioactive compounds and antioxidant activity. Propolis addition resulted in a reduced oxygenation and fortified the phenolic content of beer, content typically reduced through processes such as boiling, filtration, bottling and storage [121]. Besides the beer increasing functionality, the propolis addition could be a potential premise to improve the stability and shelf-life of craft beer. Increasing interest in beer research comes with red sorghum as a beneficial added ingredient as it is an interesting source of stilbenoids, which also possess a high antioxidant activity [122].

The evolution of phenolic compounds and antioxidant activity was also assessed throughout the brewing process [123]. It was shown that the antioxidant activity did not change during the process. Contrarily, the polyphenolic content encountered a 3-fold increase after fermentation attributed to a better extraction of polyphenols in the presence of ethanol. In another study, the late hop addition resulted in a significantly higher antioxidant activity of these beers. A high dosage late hopping was beneficial for sensory stability of beer [124].

Different beer alternatives are designed for those suffering of celiac disease, a condition characterized by intolerance to the gluten proteins found in barley and wheat. In this regard, rice malt beers (4.59-5.12\% ABV) were produced in a traditional manner using different rice malts, showing that such gluten-free beers can be considered alternatives to regular beers [19]. Adding fruits and other natural foods to beers or making them gluten-free is a sure way to increase their health appeal and become even more commercially attractive.

\section{Conclusions}

Special beers are becoming more popular and the consumption of NAB is increasing. Still, the benefits of moderate consumption are more complex to discuss and require further study. Brewers try to offer NABs with a wide range of assortments but with a conventional beer taste. As presented in this review, different studies have been performed focused mainly on the optimization of sensory characteristics and nutritional profile while new researches are in progress.

Craft breweries are prone to many challenges due to the lower production volume; moreover, access to market and efficient distribution solutions are deemed as main challenges with expensive charges. These products will gain new consumers and could fulfill the market requirements for 
products with health-promoting properties. In their support, advertising will play a powerful role by creating a positive message around special beer.

Ensuring special beer's flavor stability represents an ongoing issue of brewing involved actors, becoming one of the main technological challenges. This requires a deep understanding of the processes, equipment, and systems in place. Future studies on special beer need to be focused on characterizing the raw materials, chemical composition, different yeasts, and fermenting bacteria to modulate flavor and other sensory properties of beer for an increasingly demanding consumer. Their popularity will increase from working on innovation, sustainability, functionality, and authenticity.

Finally, it seems that beer consumers are increasingly curious about trying out different flavors and beer styles, most likely because they are looking to have a more diverse experience when drinking beer as they do not consume beer only for its alcohol content. As in any other markets, brewers need to decide if they are looking to offer a unique and safe product or if they prefer to produce a commonly accepted one with an adaptive personality, hence characteristics. This decision can only be taken after knowing the consumers demands. In this sense, it is worth noting that currently, harmful drinking patterns are declining in Europe and consumption behavior are changing towards lower strength products such as lower alcohol and non-alcohol varieties within the beer category. Given this, there is an acute need for more in-depth research on beer production techniques as it is difficult to recommend one or the other, this being up to the brewers' final interest and with expected positive and negative outcomes. Regardless of the selected brewing technology, the main scope of a brewer would be to meet consumers wishes, to keep them safe and satisfied.

Author Contributions: Conceptualization, L.C.S. and T.E.C.; writing-original draft preparation, M.V.I., L.C.S., C.R.P., T.E.C., and A.B.; writing—review and editing, L.C.S., M.V.I., A.P., and A.B.; supervision, L.C.S., T.E.C., M.T., A.P., E.M., and H.Z.; funding acquisition, L.C.S. All authors have read and agreed to the published version of the manuscript.

Funding: This research was funded by a grant from the European Foundation for Alcohol Research (ERAB), Belgium, project number Ref EA 1545.

Acknowledgments: The publication was supported by funds from the National Research Development Projects to finance excellence (PFE)-37/2018-2020 granted by the Romanian Ministry of Research and Innovation.

Conflicts of Interest: The authors declare no conflict of interest.

\section{References}

1. Violino, S.; Figorilli, S.; Costa, C.; Pallottino, F. Internet of beer: A review on smart technologies from mash to pint. Foods 2020, 9, 950. [CrossRef] [PubMed]

2. Pereira de Moura, F.; Rocha dos Santos Mathias, T. A comparative study of dry and wet milling of barley malt and its influence on granulometry and wort composition. Beverages 2018, 4, 51. [CrossRef]

3. Sohrabvandi, S.; Mousavi, S.M.; Razavi, S.H.; Mortazavian, A.M.; Rezaei, K. Alcohol-free beer: Methods of production, sensorial defects, and healthful effects. Food Rev. Int. 2010, 26, 335-352. [CrossRef]

4. Sohrabvandi, S.; Mortazavian, A.M.; Rezaei, K. Advanced analytical methods for the analysis of chemical and microbiological properties of beer. J. Food Drug Anal. 2011, 19, 202-222.

5. Salanţă, L.; Tofană, M.; Pop, C.; Pop, A.; Coldea, T. Beverage alcohol choice among university students: Perception, consumption and preferences. Bull. Univ. Agric. Sci. Vet. Med. 2017, 74, 23. [CrossRef]

6. Oak, M.; Auger, C.; Belcastro, E.; Park, S.-H.; Lee, H.; Schini-Kerth, V.B. Potential mechanisms underlying cardiovascular protection by polyphenols: Role of the endothelium. Free Radic. Biol. Med. 2018, 122, 161-170. [CrossRef] [PubMed]

7. Neto, O.J.R.; de Oliveira, T.S.; Ghedini, P.C.; Vaz, B.G.; de Souza Gil, E. Antioxidant and vasodilatory activity of commercial beers. J. Funct. Foods 2017, 34, 130-138. [CrossRef]

8. Sohrabvandi, S.; Mortazavian, A.M.; Rezaei, K. Health-related aspects of beer: A review. Int. J. Food Prop. 2012, 15, 350-373. [CrossRef]

9. De Gaetano, G.; Costanzo, S.; Di Castelnuovo, A.; Badimon, L.; Bejko, D.; Alkerwi, A.; Chiva-Blanch, G.; Estruch, R.; La Vecchia, C.; Panico, S.; et al. Effects of moderate beer consumption on health and disease: A consensus document. Nutr. Metab. Cardiovasc. Dis. 2016, 26, 443-467. [CrossRef] 
10. Mellor, D.D.; Hanna-Khalil, B.; Carson, R. A review of the potential health benefits of low alcohol and alcohol-free beer: Effects of ingredients and craft brewing processes on potentially bioactive metabolites. Beverages 2020, 6, 25. [CrossRef]

11. Bellut, K.; Krogerus, K.; Arendt, E.K. Lachancea fermentati strains isolated from Kombucha: Fundamental insights, and practical application in low alcohol beer brewing. Front. Microbiol. 2020, 11, 1-21. [CrossRef]

12. Veljovic, M.; Despotovic, S.; Stojanovic, M.; Pecic, S.; Vukosavljevic, P.; Belovic, M.; Leskosek-Cukalovic, I. The fermentation kinetics and physicochemical properties of special beer with addition of Prokupac grape variety. Chem. Ind. Chem. Eng. Q. 2015, 21, 391-397. [CrossRef]

13. Martínez, A.; Vegara, S.; Martí, N.; Valero, M.; Saura, D. Physicochemical characterization of special persimmon fruit beers using bohemian pilsner malt as a base. J. Inst. Brew. 2017, 123, 319-327. [CrossRef]

14. Dias M de, O.; Falconi, D. The evolution of craft beer industry in Brazil. J. Econ. Bus. 2018, 1. [CrossRef]

15. Humia, B.V.; Santos, K.S.; Barbosa, A.M.; Sawata, M.; da Mendonça, M.C.; Padilha, F.F. Beer molecules and its sensory and biological properties: A review. Molecules 2019, 24, 1568. [CrossRef]

16. Bogdan, P.; Kordialik-Bogacka, E. Alternatives to malt in brewing. Trends Food Sci. Technol. 2017, 65, 1-9. [CrossRef]

17. Mezgebe, A.G.; Abegaz, K.; Taylor, J.R.N. Relationship between waxy (high amylopectin) and high protein digestibility traits in sorghum and malting quality. J. Cereal Sci. 2018, 79, 319-327. [CrossRef]

18. Ducruet, J.; Rébénaque, P.; Diserens, S.; Kosińska-Cagnazzo, A.; Héritier, I.; Andlauer, W. Amber ale beer enriched with goji berries-The effect on bioactive compound content and sensorial properties. Food Chem. 2017, 226, 109-118. [CrossRef]

19. Mayer, H.; Ceccaroni, D.; Marconi, O.; Sileoni, V.; Perretti, G.; Fantozzi, P. Development of an all rice malt beer: A gluten free alternative. LWT Food Sci. Technol. 2016, 67, 67-73. [CrossRef]

20. Mascia, I.; Fadda, C.; Karabín, M.; Dostálek, P.; Del Caro, A. Aging of craft durum wheat beer fermented with sourdough yeasts. LWT Food Sci. Technol. 2016, 65, 487-494. [CrossRef]

21. Salanță, L.C.; Tofană, M.; Socaci, S.; Pop, A.; Odagiu, A.; Nagy, M.; Cuceu, A. Evaluation of volatile compounds from Hüller Bitterer variety grown in Romania by chemometric methods. J. Agroaliment. Process. Technol. 2015, 21, 231-236.

22. Salanță, L.C.; Socaci, S.A.; Tofană, M.; Mudura, E.; Pop, C.R.; Nagy, M.; Odagiu, A. Characterization of volatile components in hop pellets using in-tube extraction GC-MS analysis. Rom. Biotechnol. Lett. 2018, 23, 13541-13550.

23. Michiu, D.; Socaci, S.A.; Jimborean, M.A.; Mudura, E.; Fărcaş, A.C.; Biriş-Dorhoi, S.E.; Tofană, M. Determination of Volatile markers from Magnum hops in beer by in-tube extraction-gas chromatography-mass spectrometry. Anal. Lett. 2018, 51, 2967-2980. [CrossRef]

24. Oladokun, O.; James, S.; Cowley, T.; Dehrmann, F.; Smart, K.; Hort, J.; Cook, D. Perceived bitterness character of beer in relation to hop variety and the impact of hop aroma. Food Chem. 2017, 230, 215-224. [CrossRef]

25. Liu, S.; Ying, A.; Quek, H. Evaluation of beer fermentation with a novel yeast Williopsis saturnus. Food Technol. Biotechnol. 2016, 54, 403-412. [CrossRef]

26. Fanari, M.; Forteschi, M.; Sanna, M.; Piu, P.P.; Porcu, M.C.; D’hallewin, G.; Secchi, N.; Zinellu, M.; Pretti, L. Pilot plant production of craft fruit beer using Ohmic-treated fruit puree. J. Food Process. Preserv. 2020, 44, 1-8. [CrossRef]

27. Daenen, L.; Sterckx, F.; Delvaux, F.R.; Verachtert, H.; Derdelinckx, G. Evaluation of the glycoside hydrolase activity of a Brettanomyces strain on glycosides from sour cherry (Prunus cerasus L.) used in the production of special fruit beers. FEMS. Yeast Res. 2008, 8, 1103-1114. [CrossRef]

28. Rošul, M.; Mandić, A.; Mišan, A.; Đerić, N.; Pejin, J. Review of trends in formulation of functional beer. Food Feed Res. 2019, 46, 23-35. [CrossRef]

29. Bellut, K.; Arendt, E.K. Chance and challenge: Non-saccharomyces yeasts in nonalcoholic and low alcohol beer brewing-A review. J. Am. Soc. Brew. Chem. 2019, 77, 77-91. [CrossRef]

30. Ignat, V.M.; Salanță, L.C.; Pop, O.L.; Pop, C.R.; Tofană, M.; Mudura, E.; Coldea, T.E.; Borșa, A.; Pasqualone, A. Current functionality and potential improvements of non-alcoholic fermented cereal beverages. Foods 2020, 9, 1031. [CrossRef]

31. Riu-Aumatell, M.; Miró, P.; Serra-Cayuela, A.; Buxaderas, S.; López-Tamames, E. Assessment of the aroma profiles of low-alcohol beers using HS-SPME-GC-MS. Food Res. Int. 2014, 57, 196-202. [CrossRef] 
32. Jackowski, M.; Trusek, A. Non-alcoholic beer Production-an overview. Pol. J. Chem. Technol. 2018, 20, 32-38. [CrossRef]

33. Muller, C.; Neves, L.E.; Gomes, L.; Guimarães, M.; Ghesti, G. Processes for alcohol-free beer production: A review. Food Sci. Technol. 2020, 40, 273-281. [CrossRef]

34. Mulero-Cerezo, J.; Briz-Redón, Á.; Serrano-Aroca, Á. Saccharomyces cerevisiae var. boulardii: Valuable probiotic starter for craft beer production. Appl. Sci. 2019, 9, 3250. [CrossRef]

35. Pokrivčák, J.; Supeková, S.C.; Lančarič, D.; Savov, R.; Tóth, M.; Vašina, R. Development of beer industry and craft beer expansion. J. Food Nutr. Res. 2019, 58, 63-74.

36. da Costa Jardim, C.; de Souza, D.; Cristina Kasper Machado, I.; Massochin Nunes Pinto, L.; de Souza Ramos, R.; Garavaglia, J. Sensory profile, consumer preference and chemical composition of craft beers from Brazil. Beverages 2018, 4, 106. [CrossRef]

37. Liguori, L.; De Francesco, G.; Russo, P.; Albanese, D.; Perretti, G.; Di Matteo, M. Quality improvement of low alcohol craft beer produced by evaporative pertraction. Chem. Eng. Trans. 2015, 43, 13-18. [CrossRef]

38. Brewers Association Best Practices Guide to Quality Craft Beer. 2013. Available online: https://www. brewbound.com/news/brewers-association-releases-best-practices-guide-to-quality-craft-beer/ (accessed on 30 October 2020).

39. European beer trends. In European Beer Trends Statistics Reports; The Brewers of Europe: Bruxelles, Belgium, 2019.

40. The Contribution made by Beer to the European Economy; The brewers of Europe: Bruxelles, Belgium, 2020.

41. A Guide on How to Improve the Experience for Your Beer Shoppers; Marston's Off Trade Beer Report; Marston's Beer Company: Wolverhampton, UK, 2018.

42. Brányik, T.; Silva, D.P.; Baszczyňski, M.; Lehnert, R.; Almeida, E.; Silva, J.B. A review of methods of low alcohol and alcohol-free beer production. J. Food Eng. 2012, 108, 493-506. [CrossRef]

43. Blanco, C.A.; Andrés-Iglesias, C.; Montero, O. Low-alcohol beers: Flavor compounds, defects, and improvement strategies. Crit. Rev. Food Sci. Nutr. 2016, 56, 1379-1388. [CrossRef]

44. Ghasemi-Varnamkhasti, M.; Mohtasebi, S.S.; Rodriguez-Mendez, M.L.; Lozano, J.; Razavi, S.H.; Ahmadi, H.; Apetrei, C. Classification of non-alcoholic beer based on aftertaste sensory evaluation by chemometric tools. Expert Syst. Appl. 2012, 39, 4315-4327. [CrossRef]

45. Carvalho, F.R.; Moors, P.; Wagemans, J.; Spence, C. The influence of color on the consumer's experience of beer. Front. Psychol. 2017, 8, 1-9. [CrossRef] [PubMed]

46. Salanță, L.C.; Tofană, M.; Mudura, E.; Pop, C.R.; Pop, A.; Coldea, T.E. The alcoholic beverage consumption preference of university students: A preliminary Romanian case study. Bull. Uasvm Food Sci. Technol. 2016, 73, 33-39. [CrossRef]

47. Salanță, L.C.; Tofană, M.; Pop, C.R.; Pop, A.; Coldea, T.E.; Mihai, M. Risk Factors associated with alcohol consumption among Romanian university students- Preliminary research. Bull. UASVM Food Sci. Technol. 2018, 75, 86-89. [CrossRef]

48. Bokulich, N.A.; Bamforth, C.W. The microbiology of malting and brewing. Microbiol. Mol. Biol. Rev. 2013, 77, 157-172. [CrossRef]

49. Capece, A.; Romaniello, R.; Siesto, G.; Romano, P. Conventional and non-conventional yeasts in beer production. Fermentation 2018, 4, 38. [CrossRef]

50. Ceccaroni, D.; Sileoni, V.; Marconi, O.; De Francesco, G.; Lee, E.G.; Perretti, G. Specialty rice malt optimization and improvement of rice malt beer aspect and aroma. LWT 2019, 99, 299-305. [CrossRef]

51. Aquilani, B.; Laureti, T.; Poponi, S.; Secondi, L. Beer choice and consumption determinants when craft beers are tasted: An exploratory study of consumer preferences. Food Qual. Prefer. 2015, 41, 214-224. [CrossRef]

52. Andrés-Iglesias, C.; García-Serna, J.; Montero, O.; Blanco, C.A. Simulation and flavor compound analysis of dealcoholized beer via one-step vacuum distillation. Food Res. Int. 2015, 76, 751-760. [CrossRef]

53. Holt, S.; Miks, M.H.; De Carvalho, B.T.; Foulquié-Moreno, M.R.; Thevelein, J.M. The molecular biology of fruity and floral aromas in beer and other alcoholic beverages. Fems Microbiol. Rev. 2019, 43, 193-222. [CrossRef]

54. Menz, G.; Andrighetto, C.; Lombardi, A.; Corich, V.; Aldred, P.; Vriesekoop, F. Isolation, identification, and characterisation of beer-spoilage lactic acid bacteria from microbrewed beer from Victoria, Australia. J. Inst. Brew. 2010, 116, 14-22. [CrossRef] 
55. Malfliet, S.; Opstaele, F.; Clippeleer, J.; Syryn, E.; Goiris, K.; Cooman, L.; Aerts, G. Flavour instability of pale lager beers: Determination of analytical markers in relation to sensory ageing. J. Inst. Brew. 2008, 114, 180-192. [CrossRef]

56. Silva, A.P.; Jager, G.; van Bommel, R.; van Zyl, H.; Voss, H.P.; Hogg, T.; Pintado, M.; de Graaf, C. Functional or emotional? How Dutch and Portuguese conceptualise beer, wine and non-alcoholic beer consumption. Food Qual. Prefer. 2016, 49, 54-65. [CrossRef]

57. Wojtyra, B. How and why did craft breweries 'revolutionise' the beer market? The case of Poland. Morav. Geogr. Rep. 2020, 28, 81-97. [CrossRef]

58. Wojtyra, B.; Grudzien, Ł. Development of the beer industry in Poland in the period of "the craft beer revolution" (2011-2016). Stud. Ind. Geogr. Comm. Pol. Geogr. Soc. 2017, 31, 52-67. [CrossRef]

59. Garavaglia, C.; Swinnen, J. The craft beer revolution: An international perspective. Choices 2017, 32, 1-8.

60. Giannakopoulos, I.A. Small Firm size and Craft Production as a Sustainable Competitive Advantage. The Case of Beer in Belgium and the Netherlands. Master's Thesis, Wageningen University, Wa Geningen, The Netherlands, 2019.

61. Kloos, A.F. The economic success recipe of craft beer brewers: An Analysis of the Definition of Success and Associated Business Strategies of European Craft Beer Brewers. Master's Thesis, Wageningen University, Wageningen, The Netherlands, August 2018.

62. Callejo, M.J.; Tesfaye, W.; González, M.C.; Morata, A. Craft beers: Current situation and future trends. In New Advances on Fermentation Processes; Martínez-Espinosa, R.M., Ed.; IntechOpen: London, UK, 2019; pp. 1-18.

63. Clemons, E.K.; Gao, G.; Hitt, L.M. When online reviews meet hyperdifferentiation: A study of the craft beer industry. J. Manag. Inf. Syst 2006, 23, 149-171. [CrossRef]

64. Luneia, S.; Zannoli, R.; Farchioni, M.; Sensidoni, M.; Luneia, R. Craft beers made with addition of Umbrian legumes: Healthy and nutritional characterization. Nat. Prod. Commun. 2018, 13, 1161-1162. [CrossRef]

65. Almaguer, C.; Schönberger, C.; Gastl, M.; Arendt, E.K.; Becker, T. Humulus Lupulus-a story that begs to be told. A review. J. Inst. Brew. 2014, 120, 289-314. [CrossRef]

66. Lafontaine, S.R.; Shellhammer, T.H. Impact of static dry-hopping rate on the sensory and analytical profiles of beer. J. Inst. Brew. 2018, 124, 434-442. [CrossRef]

67. Liguori, L.; Russo, P.; Albanese, D.; Di Matteo, M. Production of Low-Alcohol Beverages: Current Status and Perspectives; Elsevier Inc: Amsterdam, The Netherlands, 2018; ISBN 9780128114476.

68. Montanari, L.; Marconi, O.; Mayer, H.; Fantozzi, P. Production of alcohol-free beer. In Beer in Health and Disease Prevention; Preedy, V.R., Ed.; Academic Press: Cambridge, MA, USA, 2009; pp. 61-75. ISBN 978-0-12-373891-2.

69. Mangindaan, D.; Khoiruddin, K.; Wenten, I.G. Beverage dealcoholization processes: Past, present, and future. Trends Food Sci. Technol. 2018, 71, 36-45. [CrossRef]

70. Ambrosi, A.; Cardozo, N.S.M.; Tessaro, I.C. Membrane separation processes for the beer industry: A review and state of the art. Food Bioprocess. Technol. 2014, 7, 921-936. [CrossRef]

71. Catarino, M.; Mendes, A.; Madeira, L.M.; Ferreira, A. Alcohol removal from beer by reverse osmosis. Sep. Sci. Technol. 2007, 42, 3011-3027. [CrossRef]

72. Pilipovik, M.V.; Riverol, C. Assessing dealcoholization systems based on reverse osmosis. J. Food Eng. 2005, 69, 437-441. [CrossRef]

73. Liguori, L.; De Francesco, G.; Russo, P.; Perretti, G.; Albanese, D.; Di Matteo, M. Quality Attributes of low-alcohol top-fermented beers produced by membrane contactor. Food Bioprocess. Technol. 2016, 9, 191-200. [CrossRef]

74. Purwasasmita, M.; Kurnia, D.; Mandias, F.C.; Khoiruddin; Wenten, I.G. Beer dealcoholization using non-porous membrane distillation. Food Bioprod. Process. 2015, 94, 180-186. [CrossRef]

75. Del Olmo, Á.; Blanco, C.A.; Palacio, L.; Prádanos, P.; Hernández, A. Pervaporation methodology for improving alcohol-free beer quality through aroma recovery. J. Food Eng. 2014, 133, 1-8. [CrossRef]

76. Prestes Alves, K.M.; da Silva, B.J.G.; de Paula Scheer, A. Beer aroma recovery and dealcoholisation by a two-step pervaporation process. J. Inst. Brew. 2020, 126, 67-76. [CrossRef]

77. Mueller, N.C.; Van der Bruggen, B.; Keuter, V.; Luis, P.; Melin, T.; Pronk, W.; Reisewitz, R.; Rickerby, D.; Rios, G.M.; Wennekes, W.; et al. Nanofiltration and nanostructured membranes-Should they be considered nanotechnology or not? J. Hazard. Mater. 2012, 211-212, 275-280. [CrossRef]

78. Muller, R. A mathematical model of the formation of fermentable sugars from starch hydrolysis during high-temperature mashing. Enzym. Microb. Technol. 2000, 27, 337-344. [CrossRef] 
79. Puerari, C.; Strejc, J.; Souza, A.C.; Karabín, M.; Schwan, R.F.; Brányik, T. Optimization of alcohol-free beer production by lager and cachaça yeast strains using response surface methodology. J. Inst. Brew. 2016, 122, 69-75. [CrossRef]

80. Juvonen, R.; Virkajärvi, V.; Priha, O.; Laitila, A. Microbiological Spoilage and Safety Risks in Non-Beer Beverages; Vtt Tiedotteita-Research Notes: Jyväskylä, Finland, 2011; ISBN 9789513877873.

81. Michiu, D.; Tofana, M.; Mudura, E.; Muntean, F. Preliminary research concerning the determination of beer wort flavor compounds during primary fermentation. Bull. Univ. Agric. Sci. Vet. Med. Cluj Napoca Agric. 2010, 67, 309-313. [CrossRef]

82. Suzuki, K.; Asano, S.; Iijima, K.; Kitamoto, K. Sake and beer spoilage lactic acid bacteria-A review. J. Inst. Brew. 2008, 114, 209-223. [CrossRef]

83. Lawton, M.R.; Alcaine, S.D. Leveraging endogenous barley enzymes to turn lactose-containing dairy by-products into fermentable adjuncts for Saccharomyces cerevisiae-based ethanol fermentations. J. Dairy Sci. 2019, 102, 2044-2050. [CrossRef] [PubMed]

84. Vilela, A. The importance of yeasts on fermentation quality and human health-promoting compounds. Fermentation 2019, 5, 46. [CrossRef]

85. Walker, G.; Stewart, G. Saccharomyces cerevisiae in the production of fermented beverages. Beverages 2016, 2, 30. [CrossRef]

86. Capece, A.; Romaniello, R.; Pietrafesa, A.; Siesto, G.; Pietrafesa, R.; Zambuto, M.; Romano, P. Use of Saccharomyces cerevisiae var. boulardii in co-fermentations with $\mathrm{S}$. cerevisiae for the production of craft beers with potential healthy value-added. Int. J. Food Microbiol. 2018, 284, 22-30. [CrossRef] [PubMed]

87. Gibson, B.; Geertman, J.M.A.; Hittinger, C.T.; Krogerus, K.; Libkind, D.; Louis, E.J.; Magalhães, F.; Sampaio, J.P. New yeasts-new brews: Modern approaches to brewing yeast design and development. FEMS Yeast Res. 2017, 17, 1-13. [CrossRef]

88. Senkarcinova, B.; Graça Dias, I.A.; Nespor, J.; Branyik, T. Probiotic alcohol-free beer made with Saccharomyces cerevisiae var. boulardii. LWT 2019, 100, 362-367. [CrossRef]

89. Değirmencioğlu, N.; Gurbuz, O.; Şahan, Y. The Monitoring, via an in vitro digestion system, of the bioactive content of vegetable juice fermented with Saccharomyces cerevisiae and Saccharomyces boulardii. J. Food Process. Preserv. 2016, 40, 798-811. [CrossRef]

90. Lazo-Vélez, M.A.; Serna-Saldívar, S.O.; Rosales-Medina, M.F.; Tinoco-Alvear, M.; Briones-García, M. Application of Saccharomyces cerevisiae var. boulardii in food processing: A review. J. Appl. Microbiol. 2018, 125, 943-951.

91. Domizio, P.; House, J.F.; Joseph, C.M.L.; Bisson, L.F.; Bamforth, C.W. Lachancea thermotolerans as an alternative yeast for the production of beer. J. Inst. Brew. 2016, 122, 599-604. [CrossRef]

92. Serra Colomer, M.; Funch, B.; Forster, J. The raise of Brettanomyces yeast species for beer production. Curr. Opin. Biotechnol. 2019, 56, 30-35. [CrossRef] [PubMed]

93. Zdaniewicz, M.; Satora, P.; Pater, A.; Bogacz, S. Low lactic acid-producing strain of lachancea thermotolerans as a new starter for beer production. Biomolecules 2020, 10, 256. [CrossRef]

94. Canonico, L.; Ciani, E.; Galli, E.; Comitini, F.; Ciani, M. Evolution of aromatic profile of Torulaspora delbrueckii mixed fermentation at microbrewery plant. Fermentation 2020, 6, 7. [CrossRef]

95. Bellut, K.; Michel, M.; Zarnkow, M.; Hutzler, M.; Jacob, F.; De Schutter, D.P.; Daenen, L.; Lynch, K.M.; Zannini, E.; Arendt, E.K. Application of non-Saccharomyces yeasts isolated from kombucha in the production of alcohol-free beer. Fermentation 2018, 4, 66. [CrossRef]

96. Canonico, L.; Agarbati, A.; Comitini, F.; Ciani, M. Torulaspora delbrueckii in the brewing process: A new approach to enhance bioflavour and to reduce ethanol content. Food Microbiol. 2016, 56, 45-51. [CrossRef] [PubMed]

97. Michel, M.; Meier-Dörnberg, T.; Jacob, F.; Methner, F.J.; Wagner, R.S.; Hutzler, M. Review: Pure non-Saccharomyces starter cultures for beer fermentation with a focus on secondary metabolites and practical applications. J. Inst. Brew. 2016, 122, 569-587. [CrossRef]

98. Rój, E.; Tadić, V.M.; Mišić, D.; Žižović, I.; Arsić, I.; Dobrzyńska-Inger, A.; Kostrzewa, D. Supercritical carbon dioxide hops extracts with antimicrobial properties. Open Chem. 2015, 13, 1157-1171. [CrossRef]

99. Mudura, E.; Coldea, T. Hop-derived prenylflavonoids and their importance in brewing technology: A review. Bull. BUASVM Food Sci. Technol. 2015, 72, 1-10. [CrossRef] 
100. Karabín, M.; Hudcová, T.; Jelínek, L.; Dostálek, P. Biologically active compounds from hops and prospects for their use. Compr. Rev. Food Sci. Food Saf. 2016, 15, 542-567. [CrossRef]

101. Mudura, E.; Coldea, T.E.; Socaciu, C.; Ranga, F.; Pop, C.R.; Rotar, A.M.; Pasqualone, A. Brown beer vinegar: A potentially functional product based on its phenolic profile and antioxidant activity. J. Serb. Chem. Soc. 2018, 83, 19-30. [CrossRef]

102. Zhao, H.; Zhao, M. Effects of mashing on total phenolic contents and antioxidant activities of malts and worts. Int. J. Food Sci. Technol. 2012, 47, 240-247. [CrossRef]

103. Zhao, H.; Li, H.; Sun, G.; Yang, B.; Zhao, M. Assessment of endogenous antioxidative compounds and antioxidant activities of lager beers. J. Sci. Food Agric. 2013, 93, 910-917. [CrossRef]

104. Wannenmacher, J.; Gastl, M.; Becker, T. Phenolic substances in beer: Structural diversity, reactive potential and relevance for brewing process and beer quality. Compr. Rev. Food Sci. Food Saf. 2018, 17, 953-988. [CrossRef]

105. Vanderhaegen, B.; Neven, H.; Verachtert, H.; Derdelinckx, G. The chemistry of beer aging-A critical review. Food Chem. 2006, 95, 357-381. [CrossRef]

106. Baert, J.J.; De Clippeleer, J.; Hughes, P.S.; De Cooman, L.; Aerts, G. On the origin of free and bound staling aldehydes in beer. J. Agric. Food Chem. 2012, 60, 11449-11472. [CrossRef]

107. Mudura, E.; Paucean, A.; Rotar, A. Rapid method for evaluation of beer stability. Bull. UASVM Agric. 2012, $69,508-509$.

108. Suruceanu, N.; Socaci, S.; Coldea, T.; Mudura, E. Revaluation of waste yeast from beer production. Bull. Univ. Agric. Sci. Vet. Med. Cluj Napoca. Food Sci. Technol. 2013, 70, 118. [CrossRef]

109. Mudura, E.; Muste, S.; Tofana, M.; Socaci, S.A.; Goina, V. Improving the hop utilization in the beer biotechnology. Bull. Univ. Agric. Sci. Vet. Med. Cluj Napoca Agric. 2008, 65, 281-286. [CrossRef]

110. Cao, L.; Zhou, G.; Guo, P.; Li, Y. Influence of pasteurising intensity on beer flavour stability. J. Inst. Brew. 2011, 117, 587-592. [CrossRef]

111. Furukawa Suárez, A.; Kunz, T.; Cortés Rodríguez, N.; MacKinlay, J.; Hughes, P.; Methner, F.J. Impact of colour adjustment on flavour stability of pale lager beers with a range of distinct colouring agents. Food Chem. 2011, 125, 850-859. [CrossRef]

112. Callemien, D.; Collin, S. Involvement of flavanoids in beer color instability during storage. J. Agric. Food Chem. 2007, 55, 9066-9073. [CrossRef]

113. Dvořáková, M.; Hulín, P.; Karabín, M.; Dostálek, P. Determination of polyphenols in beer by an effective method based on solid-phase extraction and high performance liquid chromatography with diode-array detection. Czech. J. Food Sci. 2007, 25, 182-188. [CrossRef]

114. Mcmurrough, I.; Kelly, R.; Byrne, J.; Brien, M.O.; Mcmurrough, I.; Kelly, R.; Byrne, J.; Brewing, G.; James, S.; Dublin, G. Effect of the removal of sensitive proteins and proanthocyanidins on the colloidal stability of lager beer. J. Am. Soc. Brew. Chem. 1992, 50. [CrossRef]

115. McMurrough, I.; Madigan, D.; Kelly, R.J.; Smyth, M.R. The role of flavanoid polyphenols in beer stability. J. Am. Soc. Brew. Chem. 1996, 54, 141-148. [CrossRef]

116. Olaniran, A.O.; Hiralal, L.; Mokoena, M.P.; Pillay, B. Flavour-active volatile compounds in beer: Production, regulation and control. J. Inst. Brew. 2017, 123, 13-23. [CrossRef]

117. Díaz-Rubio, M.E.; Saura-Calixto, F. Dietary fiber complex in beer. J. Am. Soc. Brew. Chem. 2009, 67, 38-43. [CrossRef]

118. Nardini, M.; Foddai, M.S. Phenolics profile and antioxidant activity of special beers. Molecules 2020, 25, 2466. [CrossRef]

119. Nardini, M.; Garaguso, I. Characterization of bioactive compounds and antioxidant activity of fruit beers. Food Chem. 2020, 305, 125437. [CrossRef]

120. Jahn, A.; Kim, J.; Bashir, K.M.I.; Cho, M. gi Antioxidant content of aronia infused beer. Fermentation 2020, 6, 71. [CrossRef]

121. Ulloa, P.A.; Vidal, J.; Ávila, M.I.; Labbe, M.; Cohen, S.; Salazar, F.N. Effect of the addition of propolis extract on bioactive compounds and antioxidant activity of craft beer. J. Chem. 2017, 2017. [CrossRef]

122. Bröhan, M.; Jerkovic, V.; Collin, S. Potentiality of red sorghum for producing stilbenoid-enriched beers with high antioxidant activity. J. Agric. Food Chem. 2011, 59, 4088-4094. [CrossRef] 
123. Leitao, C.; Marchioni, E.; Bergaentzlé, M.; Zhao, M.; Didierjean, L.; Taidi, B.; Ennahar, S. Effects of processing steps on the phenolic content and antioxidant activity of beer. J. Agric. Food Chem. 2011, 59, 1249-1255. [CrossRef]

124. Wannenmacher, J.; Cotterchio, C.; Schlumberger, M.; Reuber, V.; Gastl, M.; Becker, T. Technological influence on sensory stability and antioxidant activity of beers measured by ORAC and FRAP. J. Sci. Food Agric. 2019, 99, 6628-6637. [CrossRef]

Publisher's Note: MDPI stays neutral with regard to jurisdictional claims in published maps and institutional affiliations.

(C) 2020 by the authors. Licensee MDPI, Basel, Switzerland. This article is an open access article distributed under the terms and conditions of the Creative Commons Attribution (CC BY) license (http://creativecommons.org/licenses/by/4.0/). 